\title{
Academic detailing
}

\section{Shankar PR ${ }^{1}$, Jha $\mathbf{N}^{1}$, Piryani RM르 Bajracharya $\mathbf{O}^{3}$, Shrestha $\mathbf{R}^{3}$, Thapa $\mathbf{H S}^{4}$}

${ }^{1}$ Department of Clinical Pharmacology, ${ }^{2}$ Department of Internal Medicine, ${ }^{3}$ Department of Clinical Pharmacy, ${ }^{4}$ Department of Hospital Pharmacy, KIST Medical College, Gwarko, Nepal

\begin{abstract}
There are a number of sources available to prescribers to stay up to date about medicines. Prescribers in rural areas in developing countries however, may not able to access some of them. Interventions to improve prescribing can be educational, managerial, and regulatory or use a mix of strategies. Detailing by the pharmaceutical industry is widespread. Academic detailing (AD) has been classically seen as a form of continuing medical education in which a trained health professional such as a physician or pharmacist visits physicians in their offices to provide evidence-based information. Face-to-face sessions, preferably on an individual basis, clear educational and behavioural objectives, establishing credibility with respect to objectivity, stimulating physician interaction, use of concise graphic educational materials, highlighting key messages, and when possible, providing positive reinforcement of improved practices in follow-up visits can increase success of $\mathrm{AD}$ initiatives. $\mathrm{AD}$ is common in developed countries and certain examples have been cited in this review.

In developing countries the authors have come across reports of AD in Pakistan, Sudan, Argentina and Uruguay, Bihar state in India, Zambia, Cuba, Indonesia and Mexico. AD had a consistent, small but potentially significant impact on prescribing practices. AD has much less resources at its command compared to the efforts by the industry. Steps have to be taken to formally start AD in Nepal and there may be specific hindering factors similar to those in other developing nations.
\end{abstract}

Key words: Academic detailing, pharmaceutical industry, evidence-based information

$\mathrm{R}$ ational use of medicines (RUM) has been defined as patients receiving medications appropriate to their clinical needs, in doses that meet their own requirements, for an adequate period of time, and at the lowest cost to them and their community ${ }^{1}$. Irrational use of medicines has been and continues to be a problem the world over, both in developed and developing nations ${ }^{2}$. In Australia there has been rising concern about the costs of the Pharmaceutical Benefits Scheme (PBS) and inappropriate prescribing ${ }^{3}$. Prescribing of medicines by doctors and their use by patients has been characterized by a substantial amount of variability in both rationality and effectiveness ${ }^{4}$. Antibiotics among the most commonly used therapeutic agents account for $12 \%$ of ambulatory care prescriptions ${ }^{5}$. Antibiotics are being over prescribed in primary care, especially for respiratory tract infections ${ }^{6}$.

\section{Obtaining information about medicines}

There are numerous sources of drug information, ranging from international data bases, journals and reference books, to national or regional drug information centres, and locally produced formularies and bulletins ${ }^{7}$. Information from the pharmaceutical industry is usually readily available through all channels of communication: verbal, written and computerised. Industry promotion budgets are large and the information produced is invariably attractive and easy to digest. However, commercial sources of information often emphasise only the positive aspects of products and overlook or give little coverage to the negative aspects. Industry information may be unsystematic and biased ${ }^{8}$ and be a factor responsible for the often observed excess variation in physicians' prescriptions ${ }^{9}$.

In the United States, pharmaceutical companies employ about 90,000 detailers and spend over $\$ 7$ billion annually to market their products to physicians, spending around $\$ 15,000$ per year per physician ${ }^{10}$. Interactions between doctors and drug detailers (medical representatives) bias medical decision making, undermine public confidence and increase health care costs ${ }^{11,12}$.

Correspondence

Dr. P. Ravi Shankar

Department of Clinical Pharmacology

KIST Medical College

Kathmandu, Nepal

E-mail: ravi.dr.shankar@gmail.com 
Table 1: Characteristics of selected Academic detailing initiatives discussed in the review

\begin{tabular}{|c|c|c|c|c|c|c|c|}
\hline Country & Year & Reference & $\begin{array}{l}\text { Method } \\
\text { adopted }\end{array}$ & Subject covered & $\begin{array}{c}\text { Target } \\
\text { participants }\end{array}$ & Outcomes & $\begin{array}{l}\text { Detailing } \\
\text { provided } \\
\text { by }\end{array}$ \\
\hline France & $1998-2003$ & 31 & $\begin{array}{l}\text { Peer conducted } \\
\text { visits }\end{array}$ & Use of antibiotics & $\begin{array}{l}\text { Medical } \\
\text { practitioners }\end{array}$ & $\begin{array}{l}\text { No negative impact } \\
\text { on invasive infections } \\
\text { in children }\end{array}$ & Doctors \\
\hline $\begin{array}{l}\text { Nova Scotia, } \\
\text { Canada }\end{array}$ & & 32 & $\begin{array}{l}\text { Face to face } \\
\text { intervention }\end{array}$ & $\begin{array}{l}\text { Prescribing of } \\
\text { COX-2 inhibitors }\end{array}$ & $\begin{array}{l}\text { General } \\
\text { practitioners }\end{array}$ & $\begin{array}{l}\text { Significant decrease } \\
\text { in utilization of } \\
\text { COX-2 NSAIDS }\end{array}$ & $\begin{array}{l}\text { Dalhousie } \\
\text { University } \\
\text { Continuing } \\
\text { Medical } \\
\text { Education }\end{array}$ \\
\hline United States & 2006 & 33 & $\begin{array}{l}\text { Individual AD } \\
\text { session }\end{array}$ & $\begin{array}{l}\text { Utilization of } \\
\text { antibiotics }\end{array}$ & $\begin{array}{l}\text { Hospital } \\
\text { practitioners }\end{array}$ & $\begin{array}{l}\text { Number of } \\
\text { appropriate } \\
\text { prescriptions } \\
\text { increased }\end{array}$ & $\begin{array}{l}\text { Doctors \& } \\
\text { pharmacists }\end{array}$ \\
\hline $\begin{array}{l}\text { United } \\
\text { Kingdom }\end{array}$ & & 34 & $\begin{array}{l}\text { Individual face } \\
\text { to face sessions }\end{array}$ & $\begin{array}{l}\text { Use of antibiotics } \\
\text { in acute dental } \\
\text { pain }\end{array}$ & $\begin{array}{l}\text { General } \\
\text { dental } \\
\text { practitioners }\end{array}$ & $\begin{array}{l}\text { Fewer antibiotic } \\
\text { prescriptions \& } \\
\text { fewer inappropriate } \\
\text { antibiotics in } \\
\text { guideline group. }\end{array}$ & $\begin{array}{l}\text { Trained } \\
\text { pharmacist }\end{array}$ \\
\hline $\begin{array}{l}\text { University } \\
\text { of Utrecht, } \\
\text { Netherlands }\end{array}$ & & 35 & Group sessions & $\begin{array}{l}\text { Pharmacotherapy } \\
\text { of myocardial } \\
\text { infarction }\end{array}$ & $\begin{array}{l}\text { General } \\
\text { practitioners }\end{array}$ & $\begin{array}{l}\text { Drug therapy } \\
\text { and adherence to } \\
\text { guidelines improved. }\end{array}$ & Doctors \\
\hline $\begin{array}{l}\text { Harvard } \\
\text { Medical } \\
\text { School, } \\
\text { United States }\end{array}$ & & 36 & $\begin{array}{l}\text { Individual \& } \\
\text { group }\end{array}$ & $\begin{array}{l}\text { Use of } \\
\text { antihypertensives } \\
\text { in primary care }\end{array}$ & Clinicians & $\begin{array}{l}\text { Both group } \\
\text { and individual } \\
\text { detailing improved } \\
\text { antihypertensive } \\
\text { prescribing }\end{array}$ & Physicians \\
\hline United States & $2000-2002$ & 37 & Individual & $\begin{array}{l}\text { Prescribing of } \\
\text { antibiotics in } \\
\text { young children }\end{array}$ & $\begin{array}{l}\text { Pediatricians } \\
\text { practicing in } \\
\text { community }\end{array}$ & $\begin{array}{l}\text { AD appeared to be } \\
\text { no more effective in } \\
\text { reducing antibiotic } \\
\text { use than the practice- } \\
\text { specific report cards } \\
\text { alone }\end{array}$ & $\begin{array}{l}\text { Physician } \\
\text { leaders }\end{array}$ \\
\hline Australia & 2000 & 38 & Individual & $\begin{array}{l}\text { Prescribing of } \\
\text { addictive drugs }\end{array}$ & $\begin{array}{l}\text { Junior } \\
\text { doctors }\end{array}$ & $\begin{array}{l}\text { AD effective in } \\
\text { reducing erroneous } \\
\text { prescriptions }\end{array}$ & \\
\hline Australia & 1992 & 39 & $\begin{array}{l}\text { Individual } \\
\text { outreach visits }\end{array}$ & Use of NSAIDs & $\begin{array}{l}\text { GPs \& } \\
\text { specialists }\end{array}$ & $\begin{array}{l}\text { Sustained changes in } \\
\text { NSAID use; reduced } \\
\text { GI adverse events }\end{array}$ & \\
\hline Sudan & & 41 & $\begin{array}{l}\text { Individual \& } \\
\text { group methods }\end{array}$ & Use of antibiotics & $\begin{array}{l}\text { Prescribers } \\
\text { in primary } \\
\text { health } \\
\text { centers } \\
\end{array}$ & $\begin{array}{l}\text { Mulitfaceted } \\
\text { interventions more } \\
\text { effective }\end{array}$ & Pharmacists \\
\hline $\begin{array}{l}\text { Argentina \& } \\
\text { Uruguay }\end{array}$ & & 42 & Multifaceted & $\begin{array}{l}\text { Practices } \\
\text { associated with } \\
\text { childbirth }\end{array}$ & $\begin{array}{l}\text { Hospital } \\
\text { doctors }\end{array}$ & & Physicians \\
\hline $\begin{array}{l}\text { Rural Bihar, } \\
\text { India }\end{array}$ & & 43 & Multifaceted & $\begin{array}{l}\text { Treatment of } \\
\text { childhood illness }\end{array}$ & $\begin{array}{l}\text { Private } \\
\text { practitioners }\end{array}$ & $\begin{array}{l}\text { Improvement in } \\
\text { various aspects of } \\
\text { practitioner behavior }\end{array}$ & $\begin{array}{l}\text { Community } \\
\text { health } \\
\text { workers }\end{array}$ \\
\hline $\begin{array}{l}\text { Karachi, } \\
\text { Pakistan }\end{array}$ & & 48 & Multicomponent & $\begin{array}{l}\text { Management of } \\
\text { childhood illness }\end{array}$ & $\begin{array}{l}\text { Private } \\
\text { practitioners }\end{array}$ & $\begin{array}{l}\text { Practice of } \\
\text { practitioners more } \\
\text { consistent with IMCI } \\
\text { guidelines }\end{array}$ & $\begin{array}{l}\text { Mixed team } \\
\text { - doctors, } \\
\text { community } \\
\text { members, } \\
\text { others }\end{array}$ \\
\hline
\end{tabular}


Improving access to comprehensible, evidence-based information about medicines is an important challenge for health authorities. In recent years the Italian Ministry of Health has made efforts in expanding physicians' access to independent and evidence-based information, like freely distributing the Italian translation of Clinical Evidence and enhancing the quality of the already freely distributed NHS Drug Information Bulletin ${ }^{13}$. At the Manipal Teaching Hospital, Pokhara, Nepal a Drug Information Centre (DIC) was established in November 2003. The DIC provides objective unbiased information on drugs and therapeutics to healthcare professionals in the teaching hospital and outside ${ }^{14}$.

\section{Interventions to pro3mote rational prescribing}

Rational use of medicines requires correct prescribing, dispensing and patient concordance with treatment. Promoting RUM requires that the behaviour of all persons involved in prescribing, dispensing and patient use is addressed ${ }^{15}$. Strategies or interventions to promote the more rational use of medicines can be educational, managerial and regulatory. Educational strategies aim to inform and persuade users. In service education programs, workshops, seminars, drug information centres, drug newsletters and bulletins, a hospital formulary and standard treatment guidelines are some of the educational strategies ${ }^{15}$.

Managerial strategies include developing and implementing standard treatment guidelines, audit and feedback, clinical pharmacy programs, medicine restrictions, and avoiding perverse financial incentives. Regulatory strategies include supporting national regulations, framing and enforcing a hospital policy on pharmaceutical promotion, among others ${ }^{15}$. Successes and failures in promoting RUM in a teaching hospital in Western Nepal have been described in a recent article ${ }^{16}$. The hospital had mainly used a mix of educational and managerial strategies to promote rational prescribing. A recent paper has systematically reviewed interventions designed to improve the quality and efficiency of medication use in managed care between the years 2001 to $2007^{17}$. The study found that dissemination of educational materials alone was commonly used as a behaviour change strategy but was found to be ineffective ${ }^{17}$. This has also been shown previously ${ }^{18}$. Audit and feedback interventions compare physicians' past or current prescribing habits to those of currently accepted standards. It has been shown to achieve small to moderate improvements in physicians' prescribing practice ${ }^{19}$. Collaborationofpharmacologists/pharmacists in the health care process has emerged as a promising approach to improve the quality of care ${ }^{20}$.

\section{Pharmaceutical industry detailing}

The primary goal of detailing by the pharmaceutical industry is to promote the sale of their products. ${ }^{7}$ Medical representatives are usually very effective in promoting a product. Studies had shown that over $90 \%$ of doctors see medical representatives (MRs) and depend heavily on them as a source of information about medicines and therapeutics ${ }^{7}$.

The Guide to Good Prescribing describes how to optimize the time spent with MRs. Prescribers should obtain a copy of the officially registered drug information (data sheet) about the drug and during the presentation compare the information provided by the MR with that on the sheet. A recent study in the US had shown that certain of the claims made by drug company representatives were inconsistent with those on the drug data sheet ${ }^{21}$. Most physicians firmly believe that they are able to resist being influenced by drug companies' promotion activities according to a recent review published from Portugal ${ }^{22}$. This is however, opposite to what has been consistently reported in the literature. Portuguese physicians interact with MRs at a higher frequency compared to their colleagues in the US and Canada. The study concludes that this may put Portuguese physicians at higher risk of being influenced by the industry ${ }^{22}$.

A study had shown significant difference in perceptions in the value of services provided between physicians and pharmaceutical sales representatives. New product detailing, old product detailing, providing product studies and research findings were perceived to be less important by physicians ${ }^{23}$. However, there were no perceived differences in value as regards free samples and promotional lunches and dinners. A study in Canada had looked at the self-perceived role and educational needs of pharmaceutical representatives ${ }^{24}$. Around 98\% of the surveyed representatives agreed that they had a role in educating doctors while $52 \%$ disagreed about their main role being marketing. They also felt they had been adequately trained to detail their products but a University-accredited program would improve the quality of their detailing ${ }^{24}$.

An American study explored the dynamics of the relationship between physicians and drug representatives $^{25}$. The physicians' were aware of the negative effects of detailing but approved the relationship at a personal level. The physicians emphasised the benefits of meeting with detailers and ignored or downplayed the harms.

The Guide to Good Prescribing recommends doctors to particularly look for side effects and contraindications in the written text. They should also ask for copies of published references on efficacy and safety ${ }^{7}$. Seeing MRs is useful to learn what is new but it is important to verify and compare the information with more objective sources. 
Many academic medical centres are prohibiting visits by MRs to prescribers working their hospitals. However, the author of a recent article has argued that prohibiting visits by drug detailers to academic medical centres and interacting with doctors may be wrong. Small gifts from detailers are unlikely to create conflicts of interest for prescribers ${ }^{26}$. Calls for a ban are premised on empirical evidence for harm that is inconclusive at best, and emerging literature in economics suggests that detailing may well be socially beneficial. A study had found that pharmaceutical companies did not respond satisfactorily to requests for more information about medicines by doctors in Pakistan ${ }^{27}$. They responded more often to specialists and opinion leaders and the information provided was rarely appropriate.

\section{Academic detailing}

Academic detailing or educational outreach is a form of continuing medical education (CME) in which a trained health professional such as a physician or pharmacist visits physicians in their offices to provide evidencebased information ${ }^{28}$. The aim of academic detailing is to visit doctors and/or disseminate evidence-based information about specific drugs or drug classes after conducting impartial, independent reviews of their efficacy $^{29}$.

Academic detailing (AD) was first described in 1983 as a method of continuing medical education designed to change physicians' pharmaceutical prescribing habits ${ }^{30}$. Proponents of this method had studied the various approaches used by pharmaceutical representatives and their effectiveness and tried to use the same techniques to influence physicians' prescribing behaviour. Faceto-face sessions, preferably on an individual basis, defining clear educational and behavioural objectives, establishing credibility with respect to objectivity, stimulating physician interaction, use of concise graphic educational materials, highlighting key messages, and when possible, providing positive reinforcement of improved practices in follow-up visits are important principles of $\mathrm{AD}^{30}$.

\section{Academic detailing in developed countries}

Academic detailing is common in developed nations like the United States, United Kingdom, Europe, Australia, New Zealand, France and Canada. In the Alpes-Maritimes district of France "an antibiotics only when necessary" campaign was carried out to reduce the prescribing of antibiotics in children ${ }^{31}$. Peer conducted academic detailing visits were carried out in 2000 and 2003. Cross sectional studies showed a $9 \%$ reduction in the proportion of children who received antibiotics. In Nova Scotia, Canada, academic detailing was provided by Dalhousie University Continuing Medical Education as a face to face intervention using evidence- based information ${ }^{32}$. Academic detailing was associated with a significant decrease in the utilization of COX-2 inhibitors in the 3-month period immediately following the intervention.

In the United States (US), a pilot hospitalist delivered academic detailing intervention was carried out. The detailing session reviewed inappropriate prescribing practices and also covered current practice guidelines ${ }^{33}$. The academic detailing which included a practicebased component improved antibiotic prescribing of hospitalists in the medical centre. In the United Kingdom (UK), general dental practitioners were divided into three groups, the control, the guidelines and the intervention group ${ }^{34}$. The control group received no intervention, the guideline group received educational materials by post while the intervention group received educational material and academic detailing by a trained pharmacist. Patients in the intervention group received significantly fewer antibiotics and fewer inappropriate antibiotics compared to the control ${ }^{34}$. These sessions were based on face-to-face or individual academic detailing sessions.

In the University of Utrecht in the Netherlands, group AD sessions was conducted. The intervention consisted of scoring current cardiovascular treatment on separate forms for each patient, presenting an overview of, and discussing evidence-based treatment after myocardial infarction, defining the target population, formulating a binding consensus, and identifying patients who were eligible for improvement of pharmacotherapy ${ }^{35}$. The group detailing sessions were found to be effective in improving therapy. At the Harvard Medical School in the US, a study was conducted to compare the efficacy of individual versus group academic detailing to improve the use of antihypertensive medicines in primary care ${ }^{36}$. Individual detailing entailed a physician-educator meeting individually with clinicians to address barriers to prescribing guideline-recommended medications. The group detailing intervention incorporated the same social marketing principles in small groups of clinicians. Both were successful in improving prescribing.

In the US, a study was carried out to examine the effects of $\mathrm{AD}$ and parental education programs on the prescription of antibiotics in young children ${ }^{37}$. Physician leaders in study practices prepared educational modules and presented the modules to their practices. The control groups received only practice-specific report cards. Overall, academic detailing appeared to be no more effective in reducing antibiotic use than the practice-specific report cards alone. In Australia, it was hypothesised that AD could reduce simple errors while prescribing potentially addictive drugs. Prescription error rates were documented before and after an 
academic detailing visit to junior doctors, including the provision of a bookmark containing the requirements for this drugs ${ }^{38}$. At the hospital where the intervention was carried out there was a significant reduction in error rate and an increase in the self-confidence of junior doctors.

In Australia, an educational outreach service has been provided at a teaching hospital for community medical practitioners. In 1992 two visits focused on the better use of non-steroidal anti-inflammatory drugs (NSAIDs) ${ }^{39}$. It was concluded that a continuing education and support service for community medical practitioners which uses principally academic detailing methods in its contact with doctors has contributed to sustained changes in prescribed NSAID use over a fiveyear period. In Sweden, independent drug information was condensed and interpreted by a team and presented in both written and oral form to practitioners ${ }^{40}$. Over a period of 10 years the information/education method described here has proven sustainable and feasible in terms of providing the information and participation of the target group GPs in the oral sessions.

\section{Academic detailing in developing countries}

Academic detailing is not common in developing nations compared to the developed ones. Possible reasons could be lack of access to objective, unbiased information, lack of trained detailers, non-acceptance of pharmacists/pharmacologists as sources of medicine information by clinicians etc. We have been able to find studies describing AD in Sudan, Argentina and Uruguay, rural Bihar state in India, Zambian, Cuba, Mexico, Indonesia and Pakistan. In Sudan, a multifaceted intervention was carried out to improve prescribing practices in health centres of Khartoum state. Twenty health centres were randomly assigned to receive: (1) no intervention; (2) audit and feedback; (3) audit, feedback and seminar or (4) audit, feedback and academic detailing ${ }^{41}$. The authors concluded that multifaceted interventions involving audit and feedback combined with either academic detailing or seminars appeared to be more effective in changing prescribing practices of antibiotics than audit and feedback alone. An educational intervention to improve the healthcare provided during labour and delivery was carried out in Argentina and Uruguay ${ }^{42}$. The trial aimed to evaluate the effect of a multifaceted behavioural intervention on the use of two evidence-based birth practices, the selective use of episiotomies and active management of the third stage of labour (injection of 10 International Units of oxytocin). The results of the study are awaited. In a teaching hospital in Western Nepal, a number of initiatives have been taken to promote the more rational use of medicines ${ }^{16}$. However, academic detailing is not carried out.
In rural Bihar state in India, the INFECTOM intervention was carried out. INFECTOM consisted of standard information sessions for practitioners regarding standard case management guidelines for common childhood illnesses, Feedback based on the results of the preliminary survey, contracting practitioners to gain their commitment to specific guidelines and ongoing monitoring of their performance was done ${ }^{43}$. The intervention resulted in a significant improvement in history taking, examination and counselling aspects of common childhood illnesses. In Zambia, an increased number of appropriate antibiotic prescriptions occurred after a series of educational seminars ${ }^{44}$; in Cuba, prescribing habits improved following refresher courses in the management of acute respiratory infections ${ }^{45}$; and in Indonesia educational interactional group discussions reduced the use of injections and inappropriate antibiotics $^{46}$. Improved prescribing behavior was also observed among primary care physicians in Mexico after multiple educational interventions ${ }^{47}$. The improvement was not sustained however.

In Pakistan, INFECTOM, a multi component behavioral change strategy altered the prescribing practices of private practitioners in childhood illness ${ }^{48}$. The care provided after the intervention improved and was more consistent with Integrated Management of Childhood Illness (IMCI) algorithm.

Factors promoting and hindering academic detailing

Studies have shown factors which can hinder and promote AD. Problems of finding time, lack of faith in non-physicians delivering $\mathrm{AD}$, lack of currency and objectivity of the information provided were possible hindering factors. Relevance of the topic and quality of written material provided were the promoting (enabling) factors. In a Canadian study on perceptions of family physicians regarding $\mathrm{AD}$ a number of factors were discussed $^{27}$. Spending office time doing Continuing Medical Education (CME) was a factor which deterred most physicians. Having non-physicians deliver the educational material was found to be another significant barrier. The factors which encouraged AD were the relevance of the topics detailed, the handout material left with physicians, and the appreciation of the evidencebased approach to AD by the physicians. In a study in Belgium, the barriers mentioned by physicians to AD were doubts about the objectivity of the information, the given information was not new and the physicians had other ways to access the information ${ }^{49}$. Additional problems noted were the visits were time consuming, were politically coloured and were patronising. 


\section{Impact of academic detailing}

AD programs have been curtailed in certain countries citing lack of objective evidence of impact of the program among other factors. Providing objective evidence of impact of AD may be difficult but is essential to convince administrators and policy makers. An evaluation of the impact of Educational Outreach Visits (EOVs) has been carried out by the Cochrane database of systematic reviews. EOVs alone or when combined with other interventions had relatively consistent and small, but potentially important effects on prescribing ${ }^{50}$. Their effects on other types of professional performance vary from small to modest improvements. In the US, it was estimated that an $\mathrm{AD}$ program to improve the use of hypertensive medications resulted in a total annual individual cost saving of around 21, $711 \mathrm{US}^{51}$.

Many of the AD initiatives mentioned in this review were effective in changing prescribers' behaviour. However, a study from Denmark shows the opposite. There was no effect of $\mathrm{AD}$ on the prescribing of asthma medicines in Danish General Practice ${ }^{52}$.

\section{Lessons learnt}

$\mathrm{AD}$ is likely to be successful if the program is well thought out and discussed before implementation. $\mathrm{AD}$ has a greater chance of success if combined with other educational and managerial interventions. Use of a hospital formulary, a hospital drug list and computer aided decision support system were among the few mentioned. Individual, face to face detailing is generally considered to be more effective than group detailing but significant changes in prescribing behaviour have occurred even with group detailing. Provision of written materials has been shown to improve the effectiveness of AD. However, publicly funded AD programs have moderate budgets and staffs compared to the efforts of the pharmaceutical industry. Also the detailers do it as a part time effort coupled with their other responsibilities. It has been compared to a classic David and Goliath battle ${ }^{29}$. In Canada, AD was discontinued in the Canadian province of Alberta and may face a similar fate in the province of Manitoba. In Indonesia, small group intervention and formal seminars were compared for improving appropriate drug use $\mathrm{e}^{53}$. both interventions were equally effective in improving knowledge of prescribers about the management of acute diarrhoea. They were also partially effective in changing practitioner behaviour. Small group face to face intervention was less costly than a formal seminar and the author had recommended it for use in the primary health care system of Indonesia.

Thus it is vital to convince policy makers to continue to invest money and effort in $\mathrm{AD}$ programs in developed nations.
Academic detailing in Nepal

In Nepal AD is underdeveloped. The Drug Information Network of Nepal (DINoN) was started with the goal of providing unbiased, objective information about drugs and therapeutics to various stakeholders. Independent drug bulletins are being published by the Department of Drug Administration (DDA), the national drug regulatory authority, the Tribhuvan University Teaching Hospital, and Nepalgunj Medical College. Bulletins used to be published by the Manipal Teaching Hospital, the College of Medical Sciences, Bharatpur. These have unfortunately been discontinued.

However, AD has not been formally started. Pharmacists go for rounds with the medical team in certain institutions and serve as an important source of medicines information. At the KIST Medical College, a new medical school in Lalitpur AD sessions for prescribers and other staff members in a large group format (maximum of 30 participants). Informal feedback from the participants of the session has been positive ${ }^{54}$.

Involving pharmacists and pharmacologists in ward rounds can serve as a good beginning. The clinicians become aware of role of pharmacologists/pharmacists in providing medicines information and of their usefulness to the healthcare team. Establishment of a DIC will provide up to date, objective and unbiased information on drugs and therapeutics. Formal academic detailing sessions can now be considered. The large group format might be less expensive in terms of resources but the feasibility of one-to-one detailing can be investigated. The authors of a recent article identified lack of local health statistics, lack of awareness about evidence-based practice, challenge from pharmaceutical representatives and lack of financing capability as specific challenges to conducting AD in Nepal ${ }^{55}$. Despite these challenges an effective $\mathrm{AD}$ program can play an important role in promoting rational use of medicines.

\section{References}

1. Management Sciences for Health. Managing drug supply. West Hartford, Connecticut, USA: Kumarian Press; 1997.

2. Hogerzeil, H. V. Promoting rational prescribing: An international perspective. Brit J Clin Pharmacol. 1995;39:1-6.

3. Hill SR, Henry DD, Smith AJ. Rising prescription drug costs: whose responsibility? Med J Aust. 1997;167:6-7.

4. Avorn J, Solomon DH. Cultural and economic factors that (mis)shape antibiotic use: The nonpharmacologic basis of therapeutics. Ann Intern Med. 2000;133:128-35. 
5. McCaig LF, Hughes JM. Trends in antimicrobial drug prescribing among office-based physicians in the United States. JAMA. 1995;273:214-9.

6. Wise, R., Hart, T., Cars, O. et al. Antimicrobial resistance. Is a major threat to public health. BMJ. 1998;317:609-10.

7. de Vries TPGM, Henning RH, Hogerzeil HV, Fresle DA. Guide to good prescribing. World Health Organization: 1994.

8. Melander H, Ahlqvist-Rastad J, Meijer G, Beermann B: Evidence biased medicine selective reporting from studies sponsored by pharmaceutical industry: review of studies in new drug applications. BMJ. 2003;326:1171-3.

9. Watkins C, Moore L, Harvey I, Carthy P, Robinson E, Brawn R: Characteristics of general practitioners who frequently see drug industry representatives: national cross sectional study. BMJ. 2003;326:1178-9.

10. Consumers Union [homepage on the Internet]. Requiring Drug Companies to Disclose Marketing Expenditures to Physicians. [accessed on Aug 2008] Available at http:// www.consumersunion. org/campaigns/learn more/001813indiv.html.

11. Wazana A. Physicians and the pharmaceutical industry: Is a gift ever just a gift? JAMA. 2000;283:373-80.

12. Lexchin J. Interactions between physicians and the pharmaceutical industry: What does the literature say? CMAJ. 1993;149:1401-7.

13. Magrini N, Formoso G, Marata AM, Capelli O, Maestri E, Voci C, et al. Randomised controlled trials for evaluating the prescribing impact of information meetings led by pharmacists and of new information formats, in General Practice in Italy. BMC Health Serv Research. 2007;7:158.

14. Shankar PR, Mishra P, Subish P, Upadhyay DK. The drug information center at the Manipal Teaching Hospital - Going beyond drug information. Drug Information Journal. 2007;41:761-8.

15. Holloway K, Green T. Drug and Therapeutic Committees a practical guide. Geneva:World Health Organization; 2003.

16. Giri BR, Shankar PR. Rational use of medicines - snakes and ladders? Regional Health Forum. 2005;9:54-7.

17. Lu CY, Ross-Degnan D, Soumerai SB, Pearson SA. Interventions designed to improve the quality and efficiency of medication use in managed care: A critical review of the literature -2001-2007. BMC Health Services Research. 2008;8:75.
18. Freemantle N, Harvey EL, Wolf F, Grimshaw JM, Grilli R, Bero LA. Printed educational materials: effects on professional practice and health care outcomes. Cochrane Database of Systematic Reviews (2):CD000172, 2000.

19. Jamtvedt G, Young JM, Kristoffersen DT, O'Brien MA, Oxman AD. Does telling people what they have been doing change what they do? A systematic review of the effects of audit and feedback. Quality \& Safety in Health Care. 2006,15:433-6.

20. Gilbody S, Bower P, Fletcher J, Richards D, Sutton AJ: Collaborative care for depression: a cumulative meta-analysis and review of longerterm outcomes. Arch Int Med. 2006,166:231421.

21. Sernyak M, Rosenheck R. Experience of VA psychiatrists with pharmaceutical detailing of antipsychotic medications. Psychiatr Serv. 2007;58:1292-6

22. Granja M. Dangerous liaisons--physicians and pharmaceutical sales Representatives. Acta Med Port. 2005;18:61-8.

23. Gaedeke RM, Tootelian DH, Sanders EE. Value of services provided by pharmaceutical companies: perceptions of physicians and pharmaceutical sales representatives. Health Mark Q. 1999;17:23-31.

24. O'Donnell MJ, Molloy DW, Smith SD, Dubois S, Russo RM. The self-perceived role and educational needs of pharmaceutical representatives: a survey. Educ Health (Abingdon). 2004;17:339-45

25. Chimonas S, Brennan TA, Rothman DJ. Physicians and drug representatives: exploring the dynamics of the relationship. J Gen Intern Med. 2007;22:84-90.

26. Huddle TS. Drug reps and the academic medical center: a case for management rather than prohibition. Perspect Biol Med. 2008;51:25160.

27. Allen M, Ferrier S, O’ Connor N, Fleming I. Family physicians' perceptions of academic detailing: a quantitative and qualitative study. BMC Med Educ. 2007; 7:36.

28. Hafeez A, Mirza Z. Responses from pharmaceutical companies to doctors' requests for more drug information in Pakistan: postal survey. BMJ. 1999;319:547.

29. KondroW.Academic drug detailing: an evidencebased alternative. CMAJ. 2007;176:429-31.

30. Avorn J, Soumerai SB. Improving drug therapy decisions through educational outreach: a randomized controlled trial of 
academically based “detailing”. N Engl J Med. 1983;308:1457.

31. Blanc V, Bruno-Bazureault P, Malicki A, Berthier F, Dunais B, Touboul P, Hofliger P, Fosse T, Pradier C, Dellamonica P. "Antibiotics only when necessary" campaign in the AlpesMaritimes district: no negative impact on invasive infections in children in the community 1998-2003. [Article in French] Presse Med. 2008 Aug 1. [Epub ahead of print]

32. Graham SD, Hartzema AG, Sketris IS, Winterstein AG. Effect of an academic detailing intervention on the utilization rate of cyclooxygenase- 2 inhibitors in the elderly. Ann Pharmacother. 2008;42:749-56.

33. Kisuule F, Wright S, Barreto J, Zenilman J. Improving antibiotic utilization among hospitalists: a pilot academic detailing project with a public health approach. J Hosp Med. 2008;3:64-70.

34. Seager JM, Howell-Jones RS, Dunstan FD, Lewis MA, Richmond S, Thomas DW. A randomised controlled trial of clinical outreach education to rationalise antibiotic prescribing for acute dental pain in the primary care setting. Br Dent J. 2006;201:217-22; 216.

35. van der Elst ME, Bouvy ML, de Blaey CJ, de Boer A. Improving pharmacotherapy after myocardial infarction by group academic detailing using feedback data on a patient level. Pharmacotherapy. 2006;26:254-9.

36. Simon SR, Majumdar SR, Prosser LA, SalemSchatz S, Warner C, Kleinman K, Miroshnik I, Soumerai SB. Group versus individual academic detailing to improve the use of antihypertensive medications in primary care: a cluster-randomized controlled trial. Am J Med. 2005;118:521-8.

37. Doyne EO, Alfaro MP, Siegel RM, Atherton HD, Schoettker PJ, Bernier J, Kotagal UR. A randomized controlled trial to change antibiotic prescribing patterns in a Community. Arch Pediatr Adolesc Med. 2004;158:577-83.

38. Shaw J, Harris P, Keogh G, Graudins L, Perks E, Thomas PS. Error reduction: academic detailing as a method to reduce incorrect prescriptions. Eur J Clin Pharmacol. 2003;59:697-9.

39. May FW, Rowett DS, Gilbert AL, McNeece JI, Hurley E. Outcomes of an educational-outreach service for community medical practitioners: non-steroidal anti-inflammatory drugs. Med J Aust. 1999;170:471-4.

40. A Lundborg CS, Hensjö LO, Gustafsson LL. "Academic drug-detailing": from project to practice in a Swedish urban area. Eur J Clin Pharmacol. 1997;52:167-72

41. Awad AI, Eltayeb IB, Baraka OZ. Changing antibiotics prescribing practices in health centers of Khartoum State, Sudan. Eur J Clin Pharmacol. 2006;62:135-42.

42. Althabe F, Buekens P, Bergel E, Belizán JM, Kropp N, Wright L, Goco N, Moss N. A cluster randomized controlled trial of a behavioral intervention to facilitate the development and implementation of clinical practice guidelines in Latin American maternity hospitals: the Guidelines Trial: Study protocol [ISRCTN82417627]. BMC Womens Health. 2005;5(1):4.

43. Chakraborty S, D'Souza A, Northrup RS. Improving private practitioner care of sick children: testing new approaches in rural Bihar. Health Policy and Planning. 2000;15:400-7.

44. Bexell A, Lwando E, von Hofsten B, Tembo S, Eriksson B, Diwan VK. Improving drug use through continuing education: a randomized controlled trial in Zambia. J Clin Epidemiol. 1996;49:355-7.

45. Ochoa EG, Perez LA, Gonzalez JRB, Escobar JC, Corrales RR, Suarez GA. Prescription of antibiotics for mild acute respiratory infections in children. Bull Pan Am Health Organ. 1996;30:106-17.

46. Hadiyono JE, Suryawati S, Danu SS, Sunartono, Santoso B. Interactional group discussion: results of a controlled trial using a behavioral intervention to reduce the use of injections in public health facilities. Soc Sci Med. 1996;42:1177-83.

47. Perez-Cuevas R, Guiscafre H, Munoz O et al. Improving physician prescribing patterns to treat rhinopharyngitis. Intervention strategies in two health systems of Mexico. Soc Sci Med. 1996;42:1185-94.

48. Luby S, Zaidi N, Rehman S, Northrup R. Improving private practitioner sick-child case management in two urban communities in Pakistan. Trop Med Int Health. 2002;7:210-9.

49. Janssens I, De Meyere M, Habraken H, Soenen $\mathrm{K}$, van Driel M, Christiaens T, Bogaert $\mathrm{M}$. Barriers to academic detailers: a qualitative study in general practice. Eur J Gen Pract. 2005; 11:59-63.

50. O'Brien MA, Rogers S, Jamtvedt G, Oxman AD, Odgaard-Jensen J, Kristoffersen DT, Forsetlund L, Bainbridge D, Freemantle N, Davis DA, Haynes RB, Harvey EL. Educational outreach visits: effects on professional practice and 
health care outcomes. Cochrane Database Syst Rev. 2007;(4):CD000409.

51. Simon SR, Rodriguez HP, Majumdar SR, Kleinman K, Warner C, Salem-Schatz S, et al. Economic analysis of a randomized trial of academic detailing interventions to improve use of antihypertensive medications. J Clin Hypertens (Greenwich). 2007;9:15-20.

52. Witt K, Knudsen E, Ditlevsen S, Hollnagel H. Academic detailing has no effect on prescribing of asthma medication in Danish general practice: a 3-year randomized controlled trial with 12monthly follow-ups. Fam Pract. 2004;21:24853.
53. Santoso B. Small group intervention vs formal seminar for improving appropriate drug use. Soc Sci Med. 1996;42:1163-8.

54. Shankar PR, Jha N, Shrestha RK, Bajracharya O, Thapa HS. Academic detailing at KIST Medical College, Lalitpur, Nepal: initial experiences. Hong Kong Med J. 2009;15:404.

55. Khanal S, Palaian S, Shankar PR, Mishra P, Ibrahim MIM. Academic Detailing as a Possible Source of Drug Information in the Context of Nepal: A short review. Journal Clin Diag Research. 2009;3:1697-703. 